ECOLOGIES OF WITNESSING 
This page intentionally left blank 


\section{ECOLOGIES OF}

WITNESSING

Language, Place, and

Holocaust Testimony

Hannah Pollin-Galay

Yale UNIVERSITY PRESS

New Haven \& London 
Published with assistance from the foundation established in memory of Amasa Stone Mather of the Class of 1907, Yale College.

Copyright (C) 2018 by Yale University. All rights reserved. This book may not be reproduced, in whole or in part, including illustrations, in any form (beyond that copying permitted by Sections 107 and IO8 of the U.S. Copyright Law and except by reviewers for the public press), without written permission from the publishers.

Yale University Press books may be purchased in quantity for educational, business, or promotional use. For information, please e-mail sales.press@yale .edu (U.S. office) or sales@yaleup.co.uk (U.K. office).

Set in Galliard Old Style and Copperplate 33 types by Newgen North America. Printed in the United States of America.

Library of Congress Control Number: 201796044I

ISBN 978-0-300-22604-I (hardcover : alk. paper)

A catalogue record for this book is available from the British Library.

This paper meets the requirements of ANSI/NISO Z39.48-I992 (Permanence of Paper).

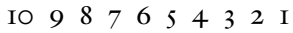


FOR ASAF 
This page intentionally left blank 